\title{
Closure of large wounds using rubber bands in rabbits
}

\section{Fechamento de grandes feridas com fita elástica de borracha em coelhos}

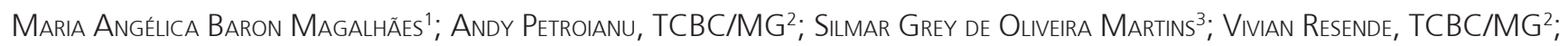 \\ Luiz Ronaldo Alberti²; Alfredo José Afonso Barbosa ${ }^{4}$; Leonardo de Souza Vasconcellos ${ }^{5}$; Wilson Campos Tavares Junior ${ }^{6}$
}

\section{A B S T R A C T}

\begin{abstract}
Objective: to verify the effectiveness of the rubber elastic band in the treatment of large wounds of the body wall of rabbits by means of traction of its edges. Methods: we studied 30 New Zealand rabbits, divided into three groups $(n=10)$ : Group 1- healing by secondary intention; Group 2- removal and eutopic repositioning of skin as full thickness skin graft; Group 3- Approximation of wound edges with elastic rubber band. In all animals, we removed a segment of the back skin and subcutaneous tissue down to the fascia, in accordance with an acrylic mold of $8 \mathrm{~cm}$ long by $12 \mathrm{~cm}$ wide. All animals were observed for 21 days. Results: two animals of groups 1 and 2 had wound abscess. In Group 2, there was partial or total graft loss in $90 \%$ of animals. The complete closure of the wounds was observed in four animals of Group 1, six of Group 2 and eight of Group 3. There was no difference between the scar resistance values of groups 2 and 3, which were higher than those in Group 1. The scars of the three groups were characterized by the presence of mature connective tissue mixed with blood vessels and inflammatory infiltration, predominantly polymorphonuclear. Conclusion: the tensile strength of the wound edges with rubber elastic band is as efficient as the skin graft to treat rabbits' large body wounds.
\end{abstract}

Key words: Abdominal Wound Closure Techniques. Surgical Wound Dehiscence. Wound Healing. Elastomers. Skin Transplantation. Connective Tissue.

\section{INTRODUCTION}

$\mathrm{L}$ arge wounds of the body wall are a surgical challenge, especially when they complicate and cause physical limitations. These wounds are characterized by difficulty in approaching their borders and their size varies in different regions of the body. They are caused byextensive trauma, large burns, cancer, pressure ulcers, infections, vascular disorders, fractures, laparostomies, etc. Although most wounds heal without infection, dehiscence or other abnormality, they can contribute to increased morbidity and mortality and treatment costs, and result in aesthetic and functional damage $e^{1,2}$.

For the choice of treatment of extensive wounds, the surgical options are the primary closure, skin grafting, local flaps and distant flaps, in order of complexity ${ }^{2,3}$. The treatment is based on predicting the final result to maintain the shape and function of the area to be reconstructed, with less risk of complications ${ }^{3}$. When there is tissue loss, the healing process is by secondary intention, by means of wound contraction. This healing occurs in open wounds or in case of dehiscence, after primary closure ${ }^{2,3}$. The main disadvantages of healing by secondary intention are the long time of treatment, the need for frequent dressing changes, electrolyte and protein loss through the wound, increased risk of infections, unsightly scars and prolonged regional immobilization ${ }^{4}$.

Skin grafts are used to shorten healing time, preventing infections and cosmetic damage, when the approximation of the wound edges is not feasible. However, this method depends on the donor site availability, which is not always possible, and predisposes patients to other complications, such as infection of the donor area and aesthetic commitment ${ }^{2,3}$.

The objective of this study was to verify the effectiveness of the rubber elastic band in the treatment of large wounds of the body wall of rabbits by means of traction of its edges.

\section{METHODS}

We studied 30 White New Zealand male rabbits (Oryctogalus cuniculus) from the experimental farm of the

1. Faculty of Medicine, Universidade Alfenas, Belo Horizonte, Minas Gerais State, Brazil; 2. Department of Surgery, Faculty of Medicine, UFMG, Minas Gerais State, Brazil; 3. Plastic Surgery, Santa Casa de Belo Horizonte, Minas Gerais State, Brazil; 4. Department of Pathology, School of Medicine, UFMG, Minas Gerais State, Brazil; 5. Department of Complementary Assessment, School of Medicine, UFMG, Minas Gerais State, Brazil; 6. Department of Radiology, University Hospital, UFMG, Minas Gerais State, Brazil. 
Veterinary School of the Universidade Federal de Minas Gerais (UFMG). At baseline, all rabbits were four months old and weighed 2,840 \pm 254 grams. These rabbits were randomly assigned to three groups and had wounds inflictedin the dorsal part of their bodies $(n=10)$ : Group 1, spontaneous healing by secondary intention; Group 2, total autogenous skin grafting; Group 3, Approximation of borders through traction with elastic rubber band.

This work followed the technical standards of research and animal testing ${ }^{5,6}$, in accordance with Law 11.794, and was approved by the Ethics Committee for Animal Experimentation of the Federal University of Minas Gerais - CETEA / UFMG, under number 145/2009.

Anesthesia was induced with an intramuscular injection in the gluteal region of $2 \%$ xylazine hydrochloride (Calmiun ${ }^{8}$, Agener Union, São Paulo), 10mg/kg, associated with $10 \%$ ketamine hydrochloride (Dopalen ${ }^{\circledR}$, Vetbrands, England), $60 \mathrm{mg} / \mathrm{kg}$. After extensive shaving the back of the animals, we performed antisepsis with polyvinylpyrrolidone solution (PVPI®), followed by alcoholic solution of $2 \%$ iodine, and placement of surgical drapes.

In all animals, the wound consisted of the removal of the skin segment and underlying subcutaneous tissue of the back down to themusculo-aponeurotic fascia. The wound followed a mold made of acrylic, measuring $12 \mathrm{~cm}$ long and $8 \mathrm{~cm}$ wide.

In Group 1, after removal of the skin, we passed four supporting stitches, $3.0 \mathrm{~cm}$ distant from each other, using 3-0 monofilament nylon sutures. The purpose of these guidelines was to anchor the wound edges in laterolateral sense, avoiding its extension by skin retraction (Figure 1A).

In Group 2, we removed all the subcutaneous tissue from the excised segment with scalpel and Metzembaun scissors. The skin consisted of all its layers down to the hypodermis was placed on the wound, as a full thickness skin graft (Figure 1B). At the end of the procedure, a Brown dressing was made with gauze fixed on the graft for six equidistant points past the wound edges with 2-0 monofilament nylon thread. This dressing kept the graft property for five days.

In Group 3, the approximation of the wound edges was obtained by means of a rubber elastic band (gominha), previously sterilized by autoclaving. The suture of these bands to the edges was initiated with a single stitch on one of the wound edges. Then, the elastic was crossed over itself, forming a " $X$ " and fixed to the skin around one inch from the edge of the wound, with separate single stitches using 3-0 monofilament nylon. During the passage of the stitches, the band was kept under moderate traction by the auxiliary. This rubber strip is crossed several times, forming consecutive " $X X$ " to the opposite vertex of the wound (Figure 1C).

After surgery, antibiotic prophylaxis was performed by subcutaneous injection of amoxicillin (Bactrosina $\AA$, Bayer, SP), 20mg / kg every 24 hours for ten days. Analgesia was achieved by oral administration of dipyrone (Novalgina ${ }^{\circledR}$, Sanofi Aventis Pharmaceuticals, England) at a dose of $25 \mathrm{mg} / \mathrm{kg}$ every 12 hours, during the first ten days postoperatively.

We washed the wounds of all rabbits daily with $0.9 \%$ saline. In Group 1, after cleaning, gauze pads soaked in petroleum jelly (Vaseline net Farmax ${ }^{\circledR}$, Farmax, Divinópolis) were placed on the wound. In Group 2, Brown dressingcompresses were soaked in petroleum jelly daily until the fifth postoperative day. After this period, the dressing was removed and new gauze soaked in petrolatum was applied daily after cleansing of the wound with $0.9 \%$ saline. In Group 3, the wounds were covered with dry gauze, so that there was no impairment of the elastic rubber band. The trunk of all the animals of the three groups was bandaged with crepe bandages to prevent contamination of wounds and the removal of dressings by therabbit.

To prevent rabbits from biting the operated area, we placed a plastic craniocervical isolation collar in all of them. This collar was adapted from a surgical helmet for dogs. For this, a wide cut in the plastic was made in a half moon shape, coinciding with the mouth of the animals. Its fixation in the rabbits' neck useda crepe bandage pierced between the forelimbs and the cervical region to allow free movement and the intake of water and food ${ }^{7}$.

At the end of the follow-up period, the rabbits underwent reoperation under anesthesia with ketamine $(100 \mathrm{mg} / \mathrm{kg})$. We removed two skin fragments from the scar - one for histological analysis and the other for the scar
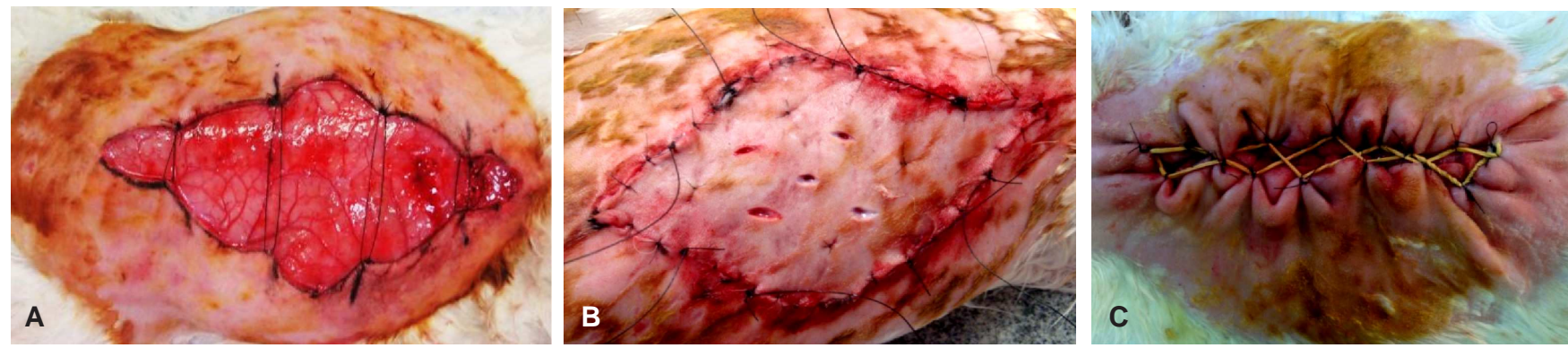

Figure 1 - Wound aspect in animals of Groups 1, 2 and 3 after completion of the associated procedures.

A) Final appearance of the wound in rabbit of Group 1 after installation of the supporting stitches. B) Final appearance of the graft in a Group 2rabbit. C) Full Approximation of wound edges with elastic rubber band. 
tensile strength test. These skin segments measured $4 \mathrm{~cm}$ long and $1 \mathrm{~cm}$ wide and contained the scar of the wound in their central part. The site chosen for collecting skin fragments was the same in all animals regardless of the appearance of the scar at the final stage, and was conducted $10 \mathrm{~cm}$ from theinsertionof the rabbits' ears.

The tissue sections prepared for histology were stained with hematoxylin and eosin (HE) and Masson trichrome. At histological evaluation, we considered: granulation tissue, young scar tissue, mature scar tissue (fibrosis), inflammatory infiltrate, granulomatous inflammation and the presence of abscesses.

To measure the scar resistance force, the removed skin fragment was clamped at both ends by two $14 \mathrm{~cm}, 30 \mathrm{~g}$ Mayo Hegar needle holders. One of the needle holders was attached to a metal support, while the other was tied to a plastic bucket with a capacity of five gallons. A water stream at a constant flow of $650 \mathrm{ml} / \mathrm{min}$ filled the bucket until the rupture of the skin fragment. We measured the liquid volume, converted in grams, which was added to the mass of the bucket and, the string and the needle holder strapped to it $(520 \mathrm{~g})$. We calculated the force to rupture the fragments using the formula: Force $($ Newton) $=$ Total Mass (grams) $\times$ Acceleration due to gravity $\left(9.8 \mathrm{~m} / \mathrm{s}^{2}\right)$.

The acceleration used was the one of the water falling on the bucket, which is the gravity acceleration, $9.8 \mathrm{~m} / \mathrm{s}^{2}$. Once the force required to rupture the scar was found, we obtained the scar rupture tension, from the formula: scar tension (megapascals) $=$ force (Newton) / area (400mm $\square$ ).

The data were presented as mean \pm standard error of the mean. To compare continuous variables in different groups, we verified the data normality using the KolmogorovSmirnov test, followed by analysis of variance (ANOVA) and multiple comparison Tukey test or the Kruskal-Wallis test for nonparametric data. Categorical variables were compared using the Fisher's exact test. All results were considered significant for a probability of significance greater than or equal to $95 \%$ (pd"0.05).

\section{RESULTS}

All animals could drink water and food without difficulty throughout the experiment.

There was no difference between groups as to animals weight of prior to operations $(p=0.1910)$ and the last day of follow-up ( $p=0.0791)$. There was a reduction in weight between the preoperative and the tenth POD in group 1, $p=0.0305$, in group $2, p=0.0004$ and in group 3 , $\mathrm{p}=0.0027$ (Table 1).

The macroscopic examination showed that two animals in Group 1 and Group 2 presented wound abscess, but none Group 3 had this complication. In Group 1 , all rabbits had bleeding in the wound during the first three postoperative days. In Group 2 and Group 3, no rabbit showed blood loss. In Group 1, there were crusting and fibrin exudates inthe wounds of all animals. In Group 2 , there was fibrinous exudate in two animals. There was total necrosis of the graft in three animals and partial necrosis of the transplanted tissue in six rabbits. In seven animals in Group 3, there was dehiscence of the suture between the eighth and 12th postoperative day, with rupture of the skin at the site of attachment points. In five animals, there was a local inflammatory reaction and fibrinous exudate, which reversed with wound cleaning.

There was no difference between groups in the number of wounds healed at 21 days $(p=0.1989)$. There was complete wound closure in four animals of the group 1, six of Group 2 and eight of the Group 3.

When comparing the scar rupture strength and tension, we found that Group 3 values were not different from those found in Group 2, but both were higher than those in Group 1 ( $p=0.0177$ ) (Table 2).

Table 1 - Values (mean \pm standard error of the mean) of the weight of the animals in Groups 1, 2 and 3, obtained preoperatively, in the tenth and $21^{\text {st }}$ DPO.

\begin{tabular}{|c|c|c|c|}
\hline \multirow[t]{2}{*}{ Group } & \multicolumn{3}{|c|}{ Weight (grams) } \\
\hline & Preoperative & $10^{\circ} \mathrm{POD}$ & $21^{\circ} \mathrm{POD}$ \\
\hline 1 & $2740 \pm 229^{A D}$ & $2419 \pm 276^{A}$ & $2600 \pm 300^{\circ}$ \\
\hline 2 & $2783 \pm 172^{\mathrm{BD}}$ & $2478 \pm 187^{B}$ & $2713 \pm 181^{\mathrm{E}}$ \\
\hline 3 & $2995 \pm 291 \mathrm{CD}$ & $2756 \pm 267^{c}$ & $2911 \pm 237^{\circ}$ \\
\hline
\end{tabular}

Group 1 -Healing by secondary intention

Group 2 -Skin grafting

Group 3 -Traction of the wound edges by elastic rubber band

$P O D$-postoperative day

$A-p=0,0305$

$B-p=0,0004$

$C-p=0,0027$

$D-p=0,1910$

$E-p=0,0791$ 
The histological findings did not differ among the three groups and were characterized by the presence of an extensive fibrosis area consisting of mature connective tissue mixed with blood vessels of the dermis and accompanying inflammatory infiltrate, consisting predominantly of polymorphonuclear cells.

\section{DISCUSSION}

Despite the large number of techniques and products available for the treatment of extensive wounds, failures are still widespread. Among the barriers to treatment, the difficulty in closing the skin is of great importance, for it brings risk of infections and other comorbidities, prolonged hospital stay and encumber treatment. The most commonly used techniques in reconstruction are complex and may contribute to increased morbidity ${ }^{8}$.

The use of elastic rubber band for large wound closure was first described in 1986 by Cohn et al. ${ }^{9}$ in the treatment of fasciotomies. These surgeons used elastic bands transfixing the wound and secured to the skin by staples. The biggest problem of this technique was the need of daily returns to the operating room, which made treatment difficult. Since then, the elastic band has been used in intervention of various types of wounds, including compartmental syndrome ${ }^{10,11}$, extensive fasciotomy wounds ${ }^{12-15}$, open fractures ${ }^{16}$, injuries from burns ${ }^{17}$ and large wounds of the body wall ${ }^{15,18}$.

In this study, we observed partial or total graft loss in $90 \%$ in Group 2, indicating the risk of failure of these procedures on animals. Rabbits, likeother animals, are very active, jeopardizing the vascularization of the graft from the wound bed during the inosculationphase ${ }^{19}$. Although widely used in humans, some grafts are rarely indicated in the treatment of extensive wounds in animals because of the possibility of complications and graft tissue $\operatorname{loss}^{20,21}$.

The use of elastic bands to traction the wound edges is an effective resource in the treatment of large wounds of the body wall9-18. This closure occurs by skin stretching, using the viscoelastic properties of the $\operatorname{skin}^{12,13,16,18}$. The biomechanical properties of the skin, resulting from the interaction between extracellular matrix components, allow it to be extended. This property is used in other techniques for closure of large skin defects, especially in tissue loss due to traumas and skin tumors ${ }^{19,22}$.

In the technique described in this work, it is appropriate to assume that all skin stretching phases are present: intrinsic extensibility, alignment of collagen fibers and cell hyperplasia. The skin elasticity and rigidity are mainly related to the thickness of its dermis and subcutaneous tissue $^{23}$. The viscoelastic properties include, among other factors, the immediate distension capacity of the skin and the resilience of its normal size after stretching. The immediate skin expansion by pulling its edges is guaranteed by its intrinsic extensibility. This property determines how much the skin can be incised in order to obtain a primary closure safely ${ }^{24}$.

The gradual stretching of the skin is stimulated by mechanical drag. When a load is applied to the skin, the tissue increases in length over time and, consequently, the force required to maintain this strain gradually decreases ${ }^{24}$ due to the arrangement of collagen fibers ${ }^{25}$. When at rest, these collagen fibers are wavy and, with stretching, the undulations flatten, the fibers extending in the same direction of the traction. As the drift increases, a greater number of fibers get aligned, to form a structure of parallel collagen fibers, resistant to stretching ${ }^{25,26}$.

Hyperplasia also plays an important role in tissue growth and results from the continuous stretching of the skin, which responds with cell proliferation and tissue growth ${ }^{27,28}$. On the other hand, fast stretching under intense traction causes disruption of collagen fibers, culminating in the formation of stretch marks ${ }^{26,28}$. Excessive stretching can also cause distension and collapse of the small vessels of the skin, leading to ischemic necrosis of the edges of the wound and dehiscence ${ }^{13,27}$

The use of elastic traction, as proposed in this research technique, allows dynamic stretchingand has the advantage of maintaining a moderate and continuous

Table 2 - Values (mean \pm standard error of the mean) of scar rupture force (Newton) and tension (Megapascal) in rabbits of groups 1,2 e 3

\begin{tabular}{lccc}
\hline Group & \multicolumn{2}{c}{ Force } & \multicolumn{2}{c}{ Voltage } \\
\hline $1^{A B C}$ & $10,696.0 \pm 2313.2$ & 26.7 & \pm \\
$2^{A B D}$ & $18,050.4 \pm 4809.5$ & 45.1 & \pm \\
$3^{A C D}$ & $15,624.9 \pm 6046.5$ & $39.0 \pm$ & 12.0 \\
\hline
\end{tabular}

Group 1 -Healing by secondary intention

Group 2 -Skin grafting

Group 3 -Traction of the wound edges by elastic rubber band

$A-p=0,0265$

$B-p<0,05$

$C-p<0,05$

$D-p>0,05$ 
traction of the wound edges, thanks to the elasticity of the rubber, which favors the juxtaposition of the edges to complete wound closure ${ }^{29}$. The pulled skin has the same characteristics regarding color, sensitivity, hair follicles and other pre-existing attachments in the wound ${ }^{26,29}$, which can be proven by clinical and histopathological findings of this study, which were not different from healing by grafting. Thus, the final aesthetic result is better than that obtained with grafting.

In this research, the final scar after closing with elastic bandshowed adequate morphological maturation and good scar resistance forthe stage it was in.

The wound closure by approximation of its edges with elastic rubber band does not depend on special experience of the surgeon or on sophisticated features. Greater care must be taken to maintain the band in moderate traction, in order not to break it and allow a continuous traction of the skin without risk of the stitches cutting it or causing its ischemia. The tension control depends on the surgeon care, since there is no feature to prevent the excessive elastic stretch. In addition, the technique proposed herein can be performed under local anesthesia, on an outpatient surgical condition.

This technique has been successfully used in large human chronic wounds arising from laparostomies, removal of tumors, fasciotomies, burns and trauma ${ }^{15,18}$. However, this is the first experimental work showing efficiency of traction of the large acute wounds edges of by anelastic rubber band on animals.

The closure of large wounds of the body wall of rabbits by means of traction of its edges with rubber elastic band is effective, simple, easy to perform, feasible and cost-effective, and should be considered in the surgical treatment of humans and animals. This technique was more effective than healing by secondary intention and as effective as the closing by grafting.

\section{Acknowledgements}

We are grateful to the Scientific Initiation students: Nayara Pereira, Marcelo Brandão, Francisco Caetano, Elidiane Lessa, Manuela Kumaira Vilchez, Carlos Cezar Martins and Simonton Almeida for cooperation in monitoring the animals.

\section{R E S U M O}

Objetivos: verificar a eficácia da fita elástica de borracha no tratamento de grandes feridas de parede corpórea de coelhos por meio da tração de suas bordas. Métodos: foram estudados 30 coelhos da raça Nova Zelândia, distribuídos em três grupos ( $n=10$ ): Grupo 1. Cicatrização por segunda intenção. Grupo 2. Retirada e reposicionamento eutópico da pele como enxerto de pele total. Grupo 3. Aproximação das bordas da ferida com fita elástica de borracha. Em todos os animais, foi retirado segmento de pele e tecido subcutâneo até a fáscia musculoaponeurótica do dorso, de acordo com um molde de acrílico, com $12 \mathrm{~cm}$ de comprimento por $8 \mathrm{~cm}$ de largura. Todos os animais foram acompanhados durante 21 dias. Resultados: dois animais dos grupos 1 e 2 apresentaram abscesso na ferida. No Grupo 2, houve perda parcial ou total do enxerto em $90 \%$ dos animais. O fechamento completo das feridas foi observado em quatro animais do Grupo 1, seis do Grupo 2 e oito do Grupo 3. Não houve diferença entre os valores de resistência cicatricial dos grupos 2 e 3, que foram maiores do que os do Grupo 1. As cicatrizes dos três grupos caracterizaram-se pela presença de tecido conjuntivo maduro entremeado por vasos sanguíneos e infiltrado inflamatório, predominantemente polimorfonuclear. Conclusão: a tração das bordas da ferida com fita elástica de borracha constitui método tão eficaz quanto o enxerto de pele para tratar grandes feridas de parede corpórea de coelhos.

Descritores: Técnicas de Fechamento de Ferimentos Abdominais. Deiscência da Ferida Operatória. Cicatrização de Feridas. Elastômeros. Enxertia de Pele. Tecido Conjuntivo.

\section{REFERENCES}

1. Kirkland KB, Briggs JP, Trivette SL, Wilkinson WE, Sexton DJ. The impact of surgical-site infections in the 1990s: attributable mortality, excess length of hospitalization, and extra costs. Infect Control Hosp Epidemiol. 1999;20(11):725-30.

2. Ferreira MC, Tuma P Jr, Carvalho VF, Kamamoto F. Complex wounds. Clinics. 2006;61(6):571-8.

3. Teixeira Neto N, Chi A, Paggiaro AO, Ferreira MC. Tratamento cirúrgico das feridas complexas. Rev Med. 2010;89(3/4):147-52.

4. Park H, Copeland C, Henry S, Barbul A. Complex wounds and their management. Surg Clin North Am. 2010;90(6):1181-94.

5. Hoff C. Sounding board. Immoral and moral uses of animals. N Eng J Med. 1980;302(2):115-8.

6. Petroianu A. Aspectos éticos na pesquisa em animais. Acta cir bras. 1996;11(3):157-64.
7. Ivo CS, Ivo MB, Salles PGO, Rosário RCV, Nunes TA. Device for craniocervical isolation in rabbits. Acta Cir Bras. 2009;24(4):31620.

8. Parrett BM, Matros E, Pribaz JJ, Orgill DP. Lower extremity trauma: trends in the management of soft-tissue reconstruction of open tibia-fibula fractures. Plast Reconstr Surg. 2006;117(4):131522; discussion 1323-4.

9. Cohn BT, Shall J, Berkowitz M. Forearm fasciotomy for acute compartment syndrome: a new technique for delayed primary closure. Orthopedics. 1986;9(9):1243-6.

10. Raskin KB. Acute vascular injuries of the upper extremity. Hand Clin. 1993;9(1):115-30.

11. Harrah J, Gates R, Carl J, Harrah JD. A simpler, less expensive technique for delayed primary closure of fasciotomias. Am J Surg. 2000;180(1): 55-7.

12. Asgari MM, Spinelli HM. The vessel loop shoelace technique for closure of fasciotomy wounds. Ann Plast Surg. 2000;44(2):225-9. 
13. Taylor RC, Reitsma BJ, Sarazin S, Bell MG. Early results using a dynamic method for delayed primary closure of fasciotomy wounds. J Am Coll Surg. 2003;197(5):872-8.

14. Ismavel R, Samuel S, Boopalan PR, Chittaranjan SB. A simple solution for wound coverage by skin stretching. J Orthop Trauma. 2011;25(3):127-32.

15. Santos ELN, Oliveira RA. Sutura elástica para o tratamento de grandes feridas. Rev Bras Cir Plást. 2012;27(3):475-7.

16. Schnirring-Judge MA, Anderson EC. Vessel loop closure technique in open fractures and other complex wounds in the foot and ankle. J Foot Ankle Surg. 2009;48(6):692-9.

17. Fan J, Wang J. The "silicone suture" for tissue expansion without an expander: a new device for repair of soft-tissue defects after burns. Plast Reconstr Surg. 2004;114(2):484-8; discussion 489-90.

18. Petroianu A. Síntese de grandes feridas da parede corpórea com tira elástica de borracha. ABCD Arq Bras Cir Dig. 2010;23(1):16-8.

19. Perlis CS, Dufresne RG Jr. Immediate skin stretching with towel clips and needles. Dermatol Surg. 2005;31(6):697-8

20. Swaim SF. Advances in wound healing in small animal practice: current status and lines of development. Vet Dermatol. 1997;8(4):249-57.

21. Beardsley SL, Schrader SC. Treatment of dogs with wounds of the limbs caused by shearing forces: 98 cases (1975-1993). J Am Vet Med Assoc. 1995;207(8):1071-5.

22. Lam AC, Nguyen QH, Tahery DP, Cohen BH, Sasaki GH, Moy RL. Decrease in skin-closing tension intraoperatively with suture tension adjustment reel, balloon expansion, and undermining. J Dermatol Surg Oncol. 1994;20(6):368-71.

23. Cua AB, Wilhelm KP, Maibach HI. Elastic properties of human skin: relation to age, sex, and anatomical region. Arch Dermatol Res. 1990;282(5):283-8.
24. Liang MD, Briggs $P$, Heckler FR, Futrell JW. Presuturing-a new technique for closing large skin defects: clinical and experimental studies. Plast Reconstr Surg. 1988;81(5):694-702.

25. Gibson T, Kenedi RM, Craik JE. The mobile micro-architecture of dermal collagen: a bio-engineering study. $\mathrm{Br} J$ Surg. 1965;52(10):764-70.

26. Melis $\mathrm{P}$, Noorlander ML, van der Horst CM, van Noorden CJ. Rapid alignment of collagen fibers in the dermis of undermined and not undermined skin stretched with a skin-stretching device. Plast Reconstr Surg. 2002;109(2):674-80; discussion 681-2.

27. Pietramaggiori G, Liu P, Scherer SS, Kaipainen A, Prsa MJ, Mayer $\mathrm{H}$, et al. Tensile forces stimulate vascular remodeling and epiderma cell proliferation in living skin. Ann Surg. 2007;246(5):896-902.

28. Daya M, Nair V. Traction-assisted dermatogenesis by serial intermittent skin tape application. Plast Reconstr Surg. 2008;122(4):1047-54.

29. Harris I. Gradual closure of fasciotomy wounds using a vessel loop shoelace. Injury. 1993;24(8):565-6.

Received 12/01/2014

Accepted for publication 15/04/2014

Conflict of interest: none

Source of funding: National Council for Scientific and Technological Development (CNPq) and the Foundation for Research of Minas Gerais State (FAPEMIG).

\section{Address for correspondence:}

Andy Petroianu

E-mail: petroian@medicina.ufmg.br 